\title{
Florida's Citrus Canker Eradication Program (CCEP): Annual Economic Impact on Florida's Processed Orange Industry 1
}

\author{
Thomas H. Spreen, Marisa L. Zansler and Ronald P. Muraro ${ }^{2}$
}

Rapid expansion and integration of international trade, increased tourism, and changes in methods of production in recent decades have increased the likelihood of the introduction of invasive species to U.S. (United States) agriculture. Invasive species can have adverse environmental and/or economic impacts when introduced into a region. Economic impacts include marketing, production, and trade implications.

One such invasive species imposing adverse economic impacts to the Florida citrus industry is a bacterial disease known as citrus canker (caused by Xanthomonas axanopodis pv. citri). Citrus canker causes lesions on the leaves, stems, and fruit of citrus trees. The disease adversely affects the proportion of fruit intended for the fresh market, serves to weaken citrus trees, and leads to a reduction in yields and higher costs of production.

The Citrus Canker Eradication Program (CCEP) was implemented in the mid-1990s in an attempt to establish guidelines for averting the spread of the disease. Currently there is no biological or chemical cure for citrus canker. All infected trees and citrus trees within a radius of 1900 feet of an infected tree must be eradicated (1900-foot rule). On-site decontamination of grove workers, field equipment, and packinghouses is also mandatory.

The current effort to eradicate citrus canker from the industry, the CCEP, has been mired in controversy associated with public opinion and legal action. A benefit-cost analysis was conducted to determine whether the CCEP is, indeed, a useful policy tool in combating the economic ramifications associated with citrus canker.

A model of the world orange juice market was originally developed at the University of Florida in 1989 by McClain and later modified in 2003 by Spreen, Brewster, and Brown. This model is a spatial equilibrium of the world orange juice market. Approximately 96 percent of Florida's orange crop is

1. This is EDIS document FE533, a publication of the Department of Food and Resource Economics, Florida Cooperative Extension Service, Institute of Food and Agricultural Sciences, University of Florida, Gainesville, FL. Published March 2005. Please visit the EDIS website at http://edis.ifas.ufl.edu.

Note: This article is one of a series of EDIS articles on the economic impacts of citrus canker on Florida's citrus industry. The series is available at http://edis.ifas.ufl.edu/TOPIC_CCEP.

2. Thomas H. Spreen, Professor and Chair, Department of Food and Resource Economics, University of Florida, Gainesville, FL; Marisa L. Zansler, Economist, Policy Analysis and Development, USDA/APHIS, Washington, D.C.; and Ronald P. Muraro, Professor and Extension Economist, Department of Food and Resource Economics, Citrus Research and Education Center, Lake Alfred, FL, Florida Cooperative Extension Service, Institute of Food and Agricultural Sciences, University of Florida, Gainesville, FL.

The Institute of Food and Agricultural Sciences (IFAS) is an Equal Opportunity Institution authorized to provide research, educational information and other services only to individuals and institutions that function with non-discrimination with respect to race, creed, color, religion, age, disability, sex, sexual orientation, marital status, national origin, political opinions or affiliations. U.S. Department of Agriculture, Cooperative Extension Service, University of Florida, IFAS, Florida A. \& M. University Cooperative Extension Program, and Boards of County Commissioners Cooperating. Larry Arrington, Dean 
sent to the processing sector; therefore, this model considers only the world processed orange market when considering Florida's orange crop (FASS, 2000). The predominant varieties in the processed orange juice market are early-midseason and Valencia varieties. Early-midseason varieties include Hamlin and Pineapple oranges.

Sao Paulo, Brazil and Florida collectively account for approximately 85 percent of the world's orange juice production (FAO, 2001). As such, events affecting Florida production impact its competitive position vis-à-vis Sao Paulo in the world orange juice market. The supply side of the model includes Florida, Brazil (Sao Paulo), California and Mexico. The demand side of the model includes consumption in the United States, the European Union, Canada, and Japan. In the United States and Canada, demand is dis-aggregated into the categories of frozen concentrated orange juice (FCOJ) and not-from-concentrate (NFC), given that NFC consumption accounts for 40 percent and 33 percent, respectively, of total orange juice consumption in these two markets (Spreen, Brewster, and Brown, 2003). In the European Union and Japan, only FCOJ demand is considered. Tariffs imposed by the United States, the European Union, and Japan are also incorporated into the model.

In a citrus canker endemic situation, the baseline model is adjusted to reflect the decline in yields. Early-midseason varieties are adjusted with a ten percent decrease in yields, and Valencia oranges are adjusted with a five percent decrease in yields (Graham and Gottwald, 1991).

\section{Empirical Results of Model}

The benefit of the Citrus Canker Eradication Program (CCEP) to the revenue of the processed orange sector is represented by the net change in on-tree revenue and the net change in F.O.B. (freight on board) revenue if citrus canker were to become endemic to Florida. The empirical results of the processed orange juice model are used to compute the net effects in this section. The benefit to the processed orange sector is represented by the loss of revenue between the baseline model and the model adjusted for yield losses under an endemic citrus canker situation.

\section{Empirical Results of Model}

The estimated economic impact of citrus canker on the annual per acre returns of processed Florida oranges is reported in Table 1. If citrus canker were to become endemic to Florida, total production of early-midseason varieties could decrease ten percent. If this occurs, it is estimated that processed utilization of early-midseason varieties would decline 12.7 million boxes, from approximately 127.5 million boxes to approximately 114.7 million boxes. The average on-tree price of early-midseason varieties would increase five percent, from $\$ 3.07$ per box to $\$ 3.23$ per box, resulting in an estimated net revenue loss of $\$ 20.3$ million.

Again, if citrus canker were to become endemic to Florida, total production of Valencia oranges could decrease five percent. If this occurs, it is estimated that processed utilization of Valencia oranges would decline approximately 4.8 million boxes, from approximately 96.1 million boxes to approximately 91.3 million boxes. The average on-tree price of Valencia oranges would increase five percent, from $\$ 4.31$ per box to $\$ 4.54$ per box, resulting in a net loss of revenue estimated at $\$ 99,000$.

Average on-tree prices would increase as a result of the reduced processed utilization in Florida since increased imports from Brazil would be insufficient to offset the decline of Florida orange juice production. Total estimated processed on-tree revenue is expected to decline by $\$ 20.4$ million as a result of endemic citrus canker.

\section{Net Effect of Citrus Canker to F.O.B. Revenue of Processed Oranges}

The estimated economic impact of endemic citrus canker on F.O.B. revenue of processed Florida oranges is the difference between the baseline model and the model adjusted for yield losses under an endemic citrus canker situation. The baseline weighted average of the F.O.B. price of all processed oranges in Florida is $\$ 1.123$ per carton. The baseline volume of early-midseason, Valencia, and temple processed orange juice is approximately 781.9 , 732.63, and 9.66 million pound solids, respectively. The total baseline volume of processed oranges is 1,524.19 million pound solids. The baseline F.O.B. 
revenue for all processed oranges in Florida is $\$ 1,711.7$ million. Under an endemic citrus canker scenario, the adjusted weighted average of the F.O.B. price of all processed oranges in Florida is $\$ 1.167$ per carton. The adjusted volume of early-midseason, Valencia, and temple processed orange juice is approximately $717.19,710.98$, and 8.46 million pound solids, respectively. The total adjusted volume of processed oranges is 1,436.63 million pound solids. The adjusted F.O.B. revenue for all processed oranges in Florida is $\$ 1,676.6$ million. Total estimated processed F.O.B. revenue is expected to decline by $\$ 35.1$ million as a result of endemic citrus canker.

\section{Additional Costs of Production}

In addition to the market analysis, partial budgeting is used to document the impact of citrus canker on the cost of production. Muraro, Roka, and Rouse (2000) and Muraro, Hebb, and Stover (2000) annually publish budgeting and costs of production for oranges and grapefruit produced in three regions of Florida. These studies are based on a survey of custom operators, input suppliers, and growers located in central Florida, southwest Florida, and the Indian River area of Florida. In a study published by Muraro, Roka, and Spreen (2001b), grower costs were estimated if citrus canker were to become endemic to Florida. The study reviewed citrus canker control programs implemented in Argentina as the basis from which to estimate cultural costs. The analysis identified six criteria for evaluating the changes in the cost structure to manage the disease as follows:

1. Capital investment cost of additional equipment for spraying.

2. Additional costs of copper sprays.

3. Costs of establishing windbreaks for fresh market varieties.

4. Value of fruit loss due to citrus canker infestation (reduced yields).

5. Certification fees.

\section{Decontamination fees.}

Muraro, Roka, and Spreen (2001b) estimate that two additional sprays would be required for fresh fruit at a cost of $\$ 59.08$ per acre. Producers of fresh fruit varieties already include copper spraying as part of their production practices; these estimated values are additional sprays. These sprays would be applied pre-bloom and at petal fall (Muraro et al., 2001b). For processed fruit, one additional spray would be needed at a cost of $\$ 32.36$ per acre. For the more susceptible varieties, an additional copper spray would be required at petal fall. Growers would apply additional sprays of copper in an attempt to mitigate the adverse effect that canker has on both fruit appearance and yield.

A major problem involving the potential spread of citrus canker is the flat terrain within the primary citrus production areas in Florida. Since the primary vector for transmission of citrus canker is wind and rain, it would be difficult for the Florida citrus industry to keep citrus canker isolated to a confined area. Establishing windbreaks to limit the spread of canker from one grove to another will be a necessity for Florida citrus grown for the fresh fruit market and the more susceptible early processed orange varieties. Muraro, Roka, and Spreen (2001b) estimate the annual cost of establishing and maintaining a windbreak at $\$ 44.89$ per acre, which includes reduced production due to removal of citrus tress for the windbreaks.

\section{Economic Impact of Citrus Canker on Delivered-In Costs of Processed Oranges}

Delivered-in costs (production/cultural costs and harvesting/pick-and-haul costs) of producing early-midseason and Valencia oranges for the processed market are estimated for a citrus canker endemic industry. The impact of citrus canker on the estimated processed costs for early-midseason oranges is reported in Table 2. The estimated total delivered-in cost for early-midseason varieties grown for the processed market, including growing, harvesting, hauling, and packing oranges, is based on the figures provided by Muraro, Roka, and Rouse (2000). Under the assumption that citrus canker 
reduces fruit yield by ten percent, per acre yields decline from 504 boxes to 453.6 boxes per acre. Grower costs increase from $\$ 758.85$ to $\$ 791.21$ per acre due to the additional costs associated with the extra copper spray cost of $\$ 32.36$. When adjusted to boxes per acre, grower costs increase approximately 16 percent, from $\$ 1.51$ to $\$ 1.74$ per box. Other costs (which include interest on operating costs, management costs, taxes, and interest on capital investment) increase roughly 11 percent, from $\$ 1.02$ to $\$ 1.14$ per box. In a citrus canker endemic industry, harvesting and Department of Citrus (DOC) assessment costs (including pick-and-haul and DOC taxes) increase from $\$ 1.98$ per box to $\$ 2.20$ per box. The total delivered-in costs for Florida's early-midseason varieties in an endemic citrus canker situation increase from $\$ 4.51$ to $\$ 5.08$ per box.

The impact of citrus canker on the estimated processed costs for Valencia oranges is reported in Table 3. The estimated total delivered-in cost for Valencia varieties grown for the processed market, including growing, harvesting, hauling, and packing oranges, is utilized based on the figures provided by Muraro, Roka, and Rouse (2000). Under the assumption that citrus canker reduces fruit yield by five percent, per acre yields decline from 504 boxes to 478.8 boxes per acre. Similar to the grower costs for early-midseason varieties, growers incur an increase from $\$ 758.85$ to $\$ 791.21$ per acre due to the additional costs associated with the extra copper spray cost of $\$ 32.36$. When adjusted to boxes, however, grower costs increase approximately ten percent, from $\$ 1.51$ to $\$ 1.65$ per box. Other costs (which include interest on operating costs, management costs, taxes, and interest on capital investment ) increase roughly five percent, from $\$ 1.02$ to $\$ 1.08$ per box. In a citrus canker endemic industry, harvesting and DOC assessment costs (which include pick-and-haul and DOC taxes) increase from $\$ 1.98$ per box to $\$ 2.08$ per box. The total delivered-in costs for Florida's Valencia oranges in an endemic citrus canker situation increase from $\$ 4.51$ to $\$ 4.81$ per box.

\section{Summary of Benefits}

In the analysis presented in this paper, the benefits of the CCEP are predicted through an analysis of the Florida citrus industry, under the scenario that citrus canker has become established. The estimated net change in revenue in the fresh and processed markets and the additional costs of production were the measurements of the predicted benefits.

Table 4 summarizes the net change in revenue for the processed orange juice market when citrus canker is introduced and becomes widely dispersed. Under the conditions associated with an industry with endemic citrus canker, the processed orange juice market is estimated to incur an overall revenue loss of \$20.4 million. Early-midseason varieties are estimated to experience the greatest revenue loss of \$20.3 million, while Valencia oranges are estimated to experience a net loss of $\$ 99,000$.

Table 5 summarizes the net change in F.O.B. revenue for the processed orange juice market when citrus canker is endemic. Under the conditions associated with an industry with endemic citrus canker, the processed orange juice market is estimated to incur an overall F.O.B. revenue loss of \$35 million.

Table 6 summarizes the estimated annual net change in the costs of producing processed oranges in an endemic citrus canker industry. Under such a scenario, the overall cost of producing oranges intended for the processed market are estimated to increase by approximately $\$ 14.4$ million. The cost of producing early-midseason varieties, which are highly susceptible to citrus canker, are estimated to increase by roughly $\$ 8.2$ million. The costs of production of Valencia oranges are estimated to increase by $\$ 6.2$ million. A summary of the net effect and economic impact if citrus canker was endemic is shown in Table 7. The total annual net reduction in on-tree and F.O.B. revenues and the net increase in the production costs for Florida processed oranges is estimated to be $\$ 69.9$ million.

The effects of the 2004 hurricane season add a new unknown in the CCEP economic analysis since the citrus canker bacteria disease is spread by rain-driven wind. Results for the economic analysis were developed in June of 2004 before Hurricanes Charley, Francis, and Jeanne passed through Florida. Continuation of the CCEP beyond 2008 would 
require a new study to estimate the economic impact of the additional costs of the CCEP along with the losses incurred by Florida's citrus industry.

\section{References}

Animal and Plant Health Inspection Service (APHIS). 2003. Citrus Canker. Washington DC: United States Department of Agriculture. Available online at http://www.aphis.usda.gov/ppq/ep/citruscanker.

Brown, M.A., T.H. Spreen, and R.P. Muraro. 1999. Fresh Versus Processed Utilization of Florida Grapefruit. Journal of Food Distribution Research 30(3):22-32.

Campbell, H., and R. Brown. 2003. Benefit-Cost Analysis: Financial and Economic Appraisal Using Spreadsheets. Cambridge, MA: Cambridge University Press.

Crawford, G.P. October 2000. Aggressive Strategy Pays Off: Citrus Canker Eradication Program Makes Progress. FloridAgriculture. Available at http://www.floridafarmbureau.org/flag/oct2k/ citrus.html.

Florida Agricultural Statistics Service (FASS). 2000. Citrus Summary 1999-2000. FASS, Orlando, FL.

Florida Department of Agriculture and Consumer Services (DACS). 2004. Report on Citrus Canker Eradication Program in Florida. Division of Plant Industry, University of Florida, Gainesville, FL. Available online at http://www.doacs.state.fl.us/pi/canker/ cankerflorida.pdf.

Florida's E-Budget 2004-2005. 2005. Florida Government, Tallahassee, FL. Available online at http://www.ebudget.state.fl.us.

Food and Agriculture Organization of the United Nations (FAO). 2001. Projections of World Production and Consumption of Citrus to 2010. China/FAO Citrus Symposium, Beijing, China (May).
Gottwald, T.R., J.H. Graham, and T.S. Schubert. 2002. Citrus Canker: The Pathogen and Its Impact. Plant Health Progress, doi: 10.1094/PHP-2002-0812-01-RV.

Graham, J.H. 2001. Varietal Susceptibility to Citrus Canker: Observations from Southern Brazil. Citrus Industry 82:15-17.

Graham, J.H., and T.R. Gottwald. 1991. Research Perspectives on Eradication of Citrus Bacterial Diseases in Florida. Plant Diseases 75:1193-1200.

McCarl, B.A., and T.H. Spreen. 1980. Price Endogenous Mathematical Programming Models as a Tool for Sector Analysis. American Journal of Agricultural Economics 62:87-102.

McClain, E.A. 1989. A Monte Carlo Simulation Model of the World Orange Juice Market. Ph.D. dissertation. Department of Food and Resource Economics, University of Florida, Gainesville, FL.

Muraro, R.P., J.W. Hebb, and E.W. Stover. Budgeting Costs and Returns for Indian River Citrus Production, 1999-2000. Economic Information Report EI-00-08. Department of Food and Resource Economics Department, University of Florida, Gainesville, FL (December).

Muraro, R.P., F.M. Roka, and R.E. Rouse. 2000. Budgeting Costs and Returns for Southwest Florida Citrus Production, 1999-2000. Economic Information Report EI-00-07. Department of Food and Resource Economics, University of Florida, Gainesville, FL (December).

Muraro, R.P., F.M. Roka, and T.H. Spreen. 2001a. An Overview of Argentina's Citrus Canker Control Program. Electronic Data Information Source (EDIS) FE285. Department of Food and Resource Economics, UF/IFAS, University of Florida, Gainesville, FL (June).

Muraro, R.P., F.M. Roka, and T.H. Spreen. 2001b. Grower Costs of Having Citrus Canker in Florida. Electronic Data Information Source (EDIS) FE286. Department of Food and Resource Economics, UF/IFAS, University of Florida, Gainesville, FL (June). 
Spreen, T.H., C. Brewster, and M.G. Brown. 2003. The Free Trade Area of the Americas and the Market for Processed Orange Products. Journal of Agricultural and Applied Economics 35(1):107-126.

Zansler, M.L. 2004. The Economic Impacts to an Industry Associated with an Invasive Species: The Case of Citrus Canker in Florida. Ph.D. dissertation, Department of Food and Resource Economics, University of Florida, Gainesville, FL (August). 
Florida's Citrus Canker Eradication Program (CCEP): Annual Economic Impact on Florida's....

Table 1. Estimated economic impact of endemic citrus canker on annual processed orange utilization in Florida, 1990-2000 season.

\begin{tabular}{|c|c|c|c|c|}
\hline Variety & Total Production & $\begin{array}{c}\text { Processed } \\
\text { Utilization }\end{array}$ & $\begin{array}{c}\text { Average On-tree } \\
\text { Price }\end{array}$ & $\begin{array}{c}\text { Processed Net } \\
\text { Revenue }\end{array}$ \\
\hline & 1,000 boxes & 1,000 boxes & $\$ / b o x$ & 1,000 dollars \\
\hline \multicolumn{5}{|l|}{ Without Citrus Canker } \\
\hline Early-Midseason $^{a}$ & 134,000 & 127,495 & 3.07 & 391,410 \\
\hline Valencia & 99,000 & 96,112 & 4.31 & 414,243 \\
\hline \multicolumn{5}{|l|}{ With Citrus Canker } \\
\hline Early-Midseason & 120,600 & 114,746 & 3.23 & 371,071 \\
\hline Valencia & 94,050 & 91,306 & 4.54 & 414,144 \\
\hline
\end{tabular}

Table 2. Estimated economic impact of endemic citrus canker on total delivered-in costs for early-midseason oranges grown for processed market, 1999-2000 season.

\begin{tabular}{|c|c|c|c|c|}
\hline & \multicolumn{2}{|c|}{ Without Citrus Canker } & \multicolumn{2}{|c|}{ With Endemic Citrus Canker } \\
\hline Total Yield (boxes/acre) & \multicolumn{2}{|c|}{504} & \multicolumn{2}{|c|}{$453.6^{\mathrm{a}}$} \\
\hline Growing Costs (per acre) & \multicolumn{2}{|c|}{$\$ 758.85$} & \multicolumn{2}{|c|}{$\$ 758.85$} \\
\hline Additional Costs (per acre): Copper Application & \multicolumn{2}{|c|}{-} & \multicolumn{2}{|c|}{$\$ 32.36$} \\
\hline & $\$ /$ Acre & $\$ / B o x$ & $\$ /$ Acre & $\$ / B o x$ \\
\hline Total Growing/Cultural Costs & 758.85 & 1.506 & 791.21 & 1.744 \\
\hline Other Costs ${ }^{\mathrm{b}}$ & 514.79 & 1.021 & 514.79 & 1.135 \\
\hline Total Grower Costs & $1,273.64$ & 2.527 & $1,306.00$ & 2.879 \\
\hline Harvesting (Pick/Spot Pick, Haul, DOC Tax) & 997.92 & 1.980 & 997.92 & 2.200 \\
\hline Total Delivered-in Costs ${ }^{c}$ & $2,271.56$ & 4.507 & $2,303.92$ & 5.079 \\
\hline \multicolumn{5}{|c|}{$\begin{array}{l}{ }^{\mathrm{a}} \text { Assume yield reduction of } 10 \% \text { in citrus canker endemic industry. } \\
{ }^{\mathrm{b}} \text { Other Costs (interest on operating (cultural costs), management, taxes/regulatory costs, and interest on average } \\
\text { capital investment). } \\
{ }^{\mathrm{c}} \text { Delivered-in Costs (total cost for fruit delivered to juice processor/fresh fruit packer; includes production/cultural costs } \\
\text { and harvesting/pick-and-haul costs). } \\
\text { Source: Muraro, R.P., F.M. Roka, and R.E. Rouse. 2000. Budgeting Costs and Returns for Southwest Florida Citrus } \\
\text { Production, 1999-2000. Economic Information Report El-00-07. Department of Food and Resource Economics, } \\
\text { University of Florida, Gainesville, FL (December). }\end{array}$} \\
\hline
\end{tabular}


Florida's Citrus Canker Eradication Program (CCEP): Annual Economic Impact on Florida's....

Table 3. Estimated economic impact of endemic citrus canker on total delivered-in costs for Valencia oranges grown for processed market, 1999-2000 season.

\begin{tabular}{|c|c|c|c|c|}
\hline & \multicolumn{2}{|c|}{ Without Citrus Canker } & \multicolumn{2}{|c|}{ With Endemic Citrus Canker } \\
\hline Total Yield (boxes/acre) & \multicolumn{2}{|c|}{504} & \multicolumn{2}{|c|}{$478.8^{\mathrm{a}}$} \\
\hline Growing Costs (per acre) & \multicolumn{2}{|c|}{$\$ 758.85$} & \multicolumn{2}{|c|}{$\$ 758.85$} \\
\hline \multirow[t]{2}{*}{ Additional Costs (per acre): Copper Application } & \multicolumn{2}{|c|}{-} & \multicolumn{2}{|c|}{$\$ 32.36$} \\
\hline & $\$ /$ Acre & $\$ / B o x$ & $\$ /$ Acre & $\$ / B o x$ \\
\hline Total Growing/Cultural Costs & 758.85 & 1.506 & 791.21 & 1.652 \\
\hline Other Costs ${ }^{b}$ & 514.79 & 1.021 & 514.79 & 1.075 \\
\hline Total Grower Costs & $1,273.64$ & 2.527 & $1,306.00$ & 2.727 \\
\hline Harvesting (Pick/Spot Pick, Haul, DOC Tax) & 997.92 & 1.980 & 997.92 & 2.084 \\
\hline Total Delivered-in Costs ${ }^{c}$ & $2,271.56$ & 4.507 & $2,303.92$ & 4.811 \\
\hline \multicolumn{5}{|c|}{$\begin{array}{l}{ }^{\mathrm{a}} \text { Assume yield reduction of } 5 \% \text { in citrus canker endemic industry. } \\
{ }^{\mathrm{b}} \text { Other Costs (interest on operating (cultural costs), management, taxes/regulatory costs, and interest on average } \\
\text { capital investment). } \\
{ }^{c} \text { Delivered-in Costs (total cost for fruit delivered to juice processor/fresh fruit packer; includes production/cultural costs } \\
\text { and harvesting/pick-and-haul costs). } \\
\text { Source: Muraro, R.P., F.M. Roka, and R.E. Rouse. 2000. Budgeting Costs and Returns for Southwest Florida Citrus } \\
\text { Production, 1999-2000. Economic Information Report El-00-07. Department of Food and Resource Economics, } \\
\text { University of Florida, Gainesville, FL (December). }\end{array}$} \\
\hline
\end{tabular}

Table 4. Estimated change in annual net revenues for Florida processed oranges associated with endemic citrus canker.

\begin{tabular}{|c|c|c|c|}
\hline \multirow[t]{2}{*}{ Variety } & \multicolumn{3}{|c|}{ Processed On-tree Revenue* } \\
\hline & Without Citrus Canker & With Citrus Canker & Net Change in Revenue \\
\hline Early-Midseason & $\$ 391,410$ & $\$ 371,071$ & $(-20,339)$ \\
\hline \multirow[t]{2}{*}{ Valencia } & 414,243 & 414,144 & (99) \\
\hline & & Estimated Net Revenue Change: & $(-20,438)$ \\
\hline
\end{tabular}

Table 5. Estimated change in annual net F.O.B. revenues for Florida processed oranges associated with endemic citrus canker.

\begin{tabular}{|ccc|}
\hline \hline & Processed F.O.B. ${ }^{*}$ Revenues & \\
Without Citrus Canker & With Citrus Canker & Project Net Change in Revenue \\
\hline $1,711,670$ & $1,676,550$ & $(-35,120)$ \\
\hline \hline
\end{tabular}


Florida's Citrus Canker Eradication Program (CCEP): Annual Economic Impact on Florida's....

Table 6. Estimated annual net change in cost production associated with endemic citrus canker in the Florida citrus industry for processed oranges.

\begin{tabular}{|c|c|c|c|}
\hline \multirow[t]{2}{*}{ Variety } & \multicolumn{3}{|c|}{ Total Processed Orange Production Costs } \\
\hline & Without Citrus Canker & With Citrus Canker & Net Change in Cost \\
\hline Early-Midseason & 574,628 & 582,814 & 8,186 \\
\hline \multirow[t]{2}{*}{ Valencia } & 433,183 & 439,354 & 6,171 \\
\hline & & Estimated Net Cost Change: & 14,357 \\
\hline
\end{tabular}

Table 7. Summary of annual net effect and economic impact of citrus canker on "on-tree" and F.O.B. revenues and on delivered-in costs of processed oranges.

\begin{tabular}{|lc|}
\hline \hline & $\begin{array}{c}\text { Net Change } \\
1,000 \text { dollars }\end{array}$ \\
\hline Estimated Net Reduction in On-Tree Revenue & 20,437 \\
Estimated Net Reduction in F.O.B. ${ }^{*}$ Revenue & 35,120 \\
Estimated Net Increase in Production Costs & 14,357 \\
Total Annual Reduced Revenues and Increased Costs & 69,914 \\
\hline${ }^{*}$ F.O.B. $=$ freight on board. & \\
\hline \hline
\end{tabular}

